[Intelligence: a new look]. Psychology. Issues, 1, pp. 111131 [in Russian].

2. Gredinarova, E.M. (1999). Razvitie tvorcheskogo myshleniia kak uslovie uspeshnogo obucheniia [The development of creative thinking as a condition for successful learning]. Practical Psychology and Social Work, 1, pp. 13-14. [in Russian].

3. Zabrotskyi, M.M. (2003). Vikova psykholohiia [Age psychology]. Kyiv,92 p. [in Ukrainian].

4. Isachenko, H.V. Formuvannia lohichnoho myslennia molodshykh shkoliariv v protsesi navchalnoi diialnosti [Formation of logical thinking of younger students in the process of educational activity]. Available at: https:// vseosvita.ua/library/formuvanna-logicnogo-mislennamolodsih-skolariv-v-procesi-navcalnoi-dialnosti107178.html [in Ukrainian].

5. Polishchuk, M.M. Rozvytok lohichnoho myslennia uchniv molodshykh klasiv na urokakh informatyky [Development of logical thinking of junior students in computer science lessons]. Available at: Retri https:// informatika.udpu.edu.ua/?page_id=2013 [in Ukrainian].

6. Prysiazhniuk, T.A. (2009). Sutnist poniattia "lohichne myslennia" [The essence of the concept of "logical thinking"]. Tezy dopovidei V Vseukrainskoi naukovoi konferentsii "Problemy ta perspektyvy nauk $v$ umovakh hlobalizatsii" - Abstracts of the 5th All-Ukrainian Scientific Conference "Problems and prospects of sciences in the conditions of globalization", Ternopil, pp.104-107. [in Ukrainian].

7. Savchenko, O. Ya. Metodyka vykorystannia informatsiinykh tekhnolohii u pochatkovii shkoli [The technique of using information technology in elementary school]. Available at: https://ivanisovainfo.files.wordpress.com $>2014 / 02$ [in Ukrainian].

8. Ianovska, T. A. (2008). Osoblyvosti rozvytku myslennia molodshykh shkoliariv $\mathrm{v}$ umovakh intehrovanoho navchannia [Features of development of thinking of younger students in the context of integrated learning]. Extended abstract of candidate's thesis. Kyiv, 22 p. [in Ukrainian].

Стаття надійшла до редакції 02.10.2019

УДК.034:373.3

DOI:

Руслана Даниляк, кандидат педагогічних наук, старший викладач кафедри педагогіки та методики початкової освіти Дрогобииького державного педагогічного університету імені Івана Франка

\title{
ПЕДАГОГІЧНІ УМОВИ ФОРМУВАННЯ МОРАЛЬНОЇ КУЛЬТУРИ УЧНІВ ПОЧАТКОВОЇ ШКОЛИ
}

У статті розглянуто педагогічні умови формування моральної культури учнів початкової школи як результату морального виховання; обтрунтовано особливості иьього процесу в освітньо-виховних конщепціях минулого і сьогодення; визначено педагогічні умови формування моральної свідомості молодших школярів.

Ключові слова: особистісно орієнтоване виховання; моральне виховання; суб'єкт виховання; педагогічні умови; моральна свідомість; вибір.

Jim. 13.

Ruslana Danylyak, Ph.D.(Pedagogy) Lecturer of the Pedagogy and Methods of Primary Education Department Drohobych Ivan Franko State Pedagogical University

\section{PEDAGOGICAL CONDITIONS OF FORMATION OF THE MORAL CULTURE OF PRIMARY SCHOOLCHILDREN}

The ways and the means of the forming of morality as a result of the moral education of the primary schoolchildren are revealed in the article. The peculiarities of this process in the educational concepts of the past and the present are substantiated. The pedagogical conditions of forming of the primary schoolchildren's moral consciousness are defined. It is found that the effectiveness of the moral education of the primary schoolchildren identifies morality which is revealed in modesty, decency, humanity. Morality in its essence is a moral which is checked in everyday life; it is detected in the primary schoolchildren's behavior, actions and different life situations. This real condition of the morality of the primary schoolchild is caused by the level of the moral consciousness development. It exists in the form of knowledge, opinions, aims, norms, feelings, values, motives of moral behavior. Children's periodicals are the effective means of the moral education of the primary schoolchildren.

It is revealed that a teacher/parents helping a child in the process of his/her education/self-education have to create appropriate pedagogical conditions. They must substantiate both their own and the children's motivation of the acts and activity. They must develop the child's ability to the reflexion; they must help children to orientate in the system of life values.

The forming of the morality of the primary schoolchildren provides not the chain of knowledge, skills and 
abilities retranslations from the area of the moral education into the systems " a teacher - a pupil", "parents - a child". It provides creation of perfect pedagogical conditions at school and outside it. In such conditions any educational problem will be experienced by a child like a vital one; it will be solved at the personal level as a choice and responsibility for its consequences.

Keywords: personally oriented education; moral education; the subject of the education; pedagogical conditions; moral consciousness; a choice.

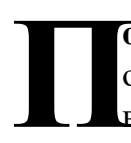

остановка проблеми. В життедіяльності особистості молодшого школяра процес виховання відбувається безперервно і різнопланово. Одним із змістових напрямів виховання $\epsilon$ моральне, у процесі якого бере участь низка суб'єктів - як персональних, так і соціальних, в межах навчального закладу, сім’ї і поза ними. При цьому важливим є використання різних шляхів і засобів, зокрема виховного потенціалу дитячої періодики. Результативність морального виховання молодшого школяра визначає моральність, конкретизована проявами доброчесності, порядності, людяності.

Формування моральності передбачає взаємопов'язані процеси вироблення цих особистісних якостей у молодшого школяра під впливом зовнішніх чинників, а також використання їх у життєдіяльності шляхом самовизначення в ситуаціях морального вибору.

Стан розробленості проблеми виявляє міжгалузевий рівень, піi вирішення потребує інтеграції наукових знань у сфері педагогіки, психології, філософії та ін. Зокрема серед численних розробок такі: психологічні механізми та закономірності процесу морального виховання особистості описані в дослідженнях Л. Божович, О. Киричука, Л. Кольберга, А. Маслоу, Л. Рувінського, Є. Субботського; характеристика процесу морального виховання молодших школярів здійснена в працях I. Беха, О. Сухомлинської, Г. Тарасенко; питанням змісту поняття "моральна вихованість особистості", а також визначенню іï структурних компонентів значну увагу приділяли М. Іванчук, I. Каіров; організаційні форми і методи морального виховання дітей на різних вікових етапах вивчали О. Савченко, Н. Скрипченко, О. Смовська, Т. Поніманська, Н. Хамська, Л. Шульга, Т. Ященко. Однак, проблема формування моральності молодшого школяра в сучасних умовах його життєдіяльності не втратила своєї актуальності, що й обумовило вибір теми публікації.

Моральному вихованню школярів присвячені різнопланові педагогічні дослідження В. Бабич, I. Зверєвої, І. Зязюна, Т. Люриної, Н. Рєпи, К. Чорної. У них підкреслюється значення для людини та сучасного суспільства загальнолюдських моральних цінностей, виховання моральних якостей особистості, вмінь та навичок моральної поведінки, формування гуманних взаємовідносин.
Метою статті $\epsilon$ виявлення та обгрунтування шляхів та засобів формування моральної культури молодших школярів як результату морального виховання у школі та поза нею. У межах визначеної мети необхідно вирішити такі завдання: визначити особливості морального виховання та його результату в освітньо-виховних концепціях минулого і сьогодення; виявити педагогічні умови цього процесу.

Виклад основного матеріалу. Критерієм вихованості в процесі морального виховання постає сформована відповідно до вікових особливостей моральність молодшого школяра. Як зазначає В. Киричок, моральність означає реальний стан моральної свідомості, стосунки, вчинки людей, тобто те, що $є$, у співвідношенні $з$ тим, що встановлено загальноприйнятими правилами і мало би бути, тобто мораллю [5, 527]. Таким чином, моральність як ознака і рівень моральної культури особистості є мораллю, перевіреною у повсякденні на практиці життя, що виявляє себе уповедінці, вчинках, найрізноманітніших життєвих ситуаціях молодшого школяра. Цей реальний стан моральності молодшого школяра обумовлений рівнем сформованості моральної свідомості, яка існує у формі знань, суджень, цілей, норм, почуттів, мотивів моральної поведінки, цінностей тощо. Моральні цінності, за Т. Аболіною, - це осмислені моральною свідомістю, етично обгрунтовані належні доброчесності (чесноти) та відповідні їм норми поведінки (мудрість, мужність, толерантність, вірність, правдивість, щирість та ін.), в яких узагальнено зміст основних етичних понять (добро і зло, справедливість, щастя, гідність, честь, обов'язок тощо) і принципів (альтруїзм, гуманізм, благоговіння перед життям та ін.), названо безпосередньо значимі для людини універсальні зразки, вимоги, ідеали моралі, які мають самостійний статус, схвалюються суспільною думкою, знаходять втілення в праві, релігії, мистецтві, філософії $[1,708]$. Таким чином, складовими моральної вихованості особистості молодшого школяра є моральна свідомість, моральні почуття, моральна поведінка та моральні якості, зміст яких понятійно в узагальненні передаємо універсальним поняттям “чеснота" (“доброчесність”).

Проблема формування моральності як результату морального виховання, моральної 


\section{ПЕДАГОГІЧНІ УМОВИ ФОРМУВАННЯ МОРАЛЬНОЇ КУЛЬТУРИ УЧНІВ ПОЧАТКОВОЇ ШКОЛИ}

вихованості молодших школярів визначена сукупністю цільового, операційного та результативного компонентів процесу виховання. Це, перш за все, реалізація мети морального виховання молодших школярів, яка полягає в становленні морально стійкої, цілісної, гармонійно розвиненої особистості. Сутність операційнотехнологічного компоненту становлять теоретико-методичні підходи організації виховного процесу як в межах навчального закладу, так і поза ним. Результативний компонент процесу морального виховання молодших школярів вказує на сформовану відповідно до вікових особливостей моральну свідомість молодшого школяра як критерій його моральної вихованості. Слід пам'ятати, що теоретико-методологічні принципи організації виховного процесу безпосередньо відображають культурноісторичну епоху, в якій відбувається цей процес виховання, адже, як зазначає О. Кононко, кожній суспільно-економічній формації відповідає особливий тип виховання $[6,88]$.

Сучасна методологія освіти найважливішим принципом осмислення та організації процесу виховання визначає співвідношення індивіда i суспільства, єднання яких по-різному трактують чисельні концепції про виховання. Їх розмаїття може бути узагальнене до двох основних напрямків: сцієнтистсько-технократичного та антисцієнтистського. Для представників сцієнтистсько-технократичного напрямку характерним $€$ прагнення до раціоналізації процесу виховання, розробки наукових виховних технологій, що грунтуються на конкретних наукових знаннях. У вихованні тут домінує практична, утилітарна мета адаптації індивіда до вимог соціального середовища (соціалізація), гармонізації відносин індивіда і суспільства. Якщо у сцієнтистськотехнократичному напрямку соціалізація особистості трактується як їі інтеграція до соціальної системи, то в антисцієнтизмі акцент зроблено на розумінні соціалізації як самоствердження особистості.

Прихильники антисцієнтизму процес виховання трактують не як реалізацію задумів вихователя, а як процес власного саморозвитку індивіда, його самовиховання і самореалізацію, а головну мету вбачають в тому, щоб зменшити процес маніпулювання поведінкою вихованців, заперечують конформізацію (пристосовництво), авторитаризм у вихованні. Прагнучи реалізувати гуманістичні ідеали, спираючись на ідеї, розроблені “філософією життя”, екзистенціалістами, вони вважають, що формування унікальної й неповторної особистості - це головна мета виховання. А формування морально-етичної, художньо-естетичної та іншої ціннісної орієнтації особи не може бути зведено лише до передачі їй знаково-вербальної інформації, яка грунтується на повідомленні та поясненні, трансляції, ретрансляції, копіюванні знань та вмінь, передачі значень і логічних зв'язків. Виховання передбачає відповідний вплив на чуття та емоції людини, вимагає обов'язкового залучення особистісних рис вихованця до процесу виховання, а тому не може здійснюватися тільки раціональним шляхом. Механізми залучення тут базуються на співчутті, співучасті та співпереживанні [3, 134 - 136].

В останні роки в Україні як аналогічні названим сцієнтистсько-технократичній та антисцієнтистській концепціям виховання утвердилися поняття, відповідно: “авторитарне виховання” і “гуманістичне виховання”, “особистісно орієнтоване навчання і виховання".

В освітньому просторі до кінця ХХ ст. офіційно панувала теорія авторитарного (комуністичного) виховання, основні положення якої знаходилися в руслі сцієнтистського напрямку, водночас, педагогічні творчі пошуки Ш. Амонашвілі, I. Волкова, Т. Гончарової, Є. Ільїна, В. Шаталова та інших [9] грунтувалися на гуманістичній педагогіці. Важливо, що українська виховна традиція в єдності теорії i практики, персоніфікована в минулому і сьогоденні іменами Г. Сковороди, К. Ушинського, П. Юркевича, С. Русової, В. Сухомлинського, М. Стельмаховича, Н. Скотної, О. Вишневського, М. Свтуха, О. Сухомлинської та інших, відповідає вимогам і принципам гуманістичного, особистісно орієнтованого виховання. Сучасна педагогічна наука утверджує принципи гуманістичної парадигми виховання, яка заснована на педагогічній взаємодії усіх суб'єктів виховного процесу.

Показниками моральної вихованості індивіда в радянській (сцієнтистсько-технократичній, авторитарній) педагогіці було визначено такі якості, як слухняність, гарні манери, ввічливість, скромність, дисциплінованість, сміливість, чесність, правдивість, працелюбність, колективізм, патріотизм, а також моральна свідомість, моральні знання, моральні ідеали, міжособистісні стосунки в дитячому колективі, рівень дитячої самосвідомості, трудової активності, вимогливість до себе, ставлення до вчителя [7; 12].

У даних визначеннях критеріїв вихованості звернемо увагу на поняття “слухняність” і “дисциплінованість”, як вимоги авторитарної педагогіки. Важливо, що у психолого-педагогічній довідниковій літературі ми не знайшли визначення 
цих понять. Первинне значення поняття “слухняність" дає академічний словник української мови як властивість за значенням “слухняний” того, хто “слухається кого-небудь, завжди підкоряється, не суперечить нікому; покірний, послушний; який виражає покірність; сповнений послуху" [12]. Відповідно, поняття “дисциплінованість” означує властивість і якість того, хто має звичку та уміє дотримуватися дисципліни - “твердо встановлений порядок, дотримання якого є обов’ язковим для всіх членів даного колективу; витриманість, звичка до суворого порядку [4]. Таким чином, слухняність i дисциплінованість передбачають застосування вихователем таких засобів як примус і покарання, що суперечить меті виховання вільної, активної, гармонійно розвиненої особистості та суті особистісно орієнтованої технології навчання і виховання, а вимога слухняності i дисциплінованості у процесі виховання спонукає дитину пристосовуватися до обставин. Однак, слід враховувати, що, за Л. Кольбергом, молодший шкільний вік - це період так званого “доморального” розвитку особистості, складовими якого є: “слухняність через страх покарання і діяльність для задоволення” (до 7 років), “підкорення авторитету і опора на авторитет" (7 - 12 років).

У цей період самосвідомість дитини формується в стосунках з оточуючим світом в еволюції від “Я-об’єкт” до “Я-суб'єкт” цього світу $[13,50]$. Тут очевидною є дилема: слухняність як поведінкова реакція дитини на примус дорослого i життєвих обставин та слухняність як поведінковий вибір самої дитини. Слухняність, на наш погляд, повинна стати особистісним вибором дитини, що можливе у ситуації сприйняття нею Добра як засадничої, універсальної моральноетичної цінності і розуміння наслідків свого послуху/непослуху у вимірі добра для себе та інших. Таким чином, молодший школяр повинен засвоїти, за Л. Кольбергом, на “доморальному” рівні своєї моральної вихованості, що саме він $\epsilon$ суб'єктом вибору у будь-якій ситуації життєдіяльності. Завдання вчителя/вихователя при цьому проаналізувати спільно 3 дитиною наслідки цього вибору, що поступово формуватиме відповідальність дитини за власний вибір, поведінкові норми, особистісну систему цінностей тощо.

Згідно з вимогами гуманістичної педагогіки і психології морально виховати не означає сформувати певні компетенції у дитини молодшого шкільного віку, які наперед визначені вчителем/батьками, а допомогти їй стати суб'єктом власного вибору. Афористично про цю педагогічну настанову сказав англійський письменник Р. Олдингтон: “Всьому, що необхідно знати, навчити не можна, вчитель може зробити тільки одне - вказати дорогу ..." [8, 27]. Допомагаючи дитині у процесі їі морального виховання/самовиховання, вчитель/батьки покликані створити належні педагогічні умови, зокрема:

- обгрунтувати мотивацію дій і діяльності дитини і власну;

- розвинути здатність дитини до рефлексії, тобто до аналізу власного психічного стану, до роздумів про себе та свою діяльність, що дасть їй уявлення про те, як вона і їі діяльність сприймаються іншими;

- допомогти зорієнтуватися в системі життєвих цінностей та наблизити до пізнання ключового питання індивідуального світогляду - про сенс життя загалом і власного зокрема;

- забезпечити автономність, творчий характер будь-якої особистісно важливої діяльності;

- сприяти самореалізації дитини, іії прагненню до визнання оточуючими власного “я”;

- забезпечити поєднання духовних та утилітарних цілей в процесі життєдіяльності дитини.

Досконалі педагогічні умови реалізують на практиці настанови гуманістичної парадигми виховання, а саме забезпечать: статус учня як основного суб' єкта процесу навчання і виховання; розвиток індивідуальних здібностей учня; застосування дидактичних засобів з урахуванням особистісного досвіду учня.

Висновки. Формування моральної культури молодшого школяра передбачає не ланцюжок ретрансляцій знань, вмінь і навичок зі сфери морального виховання у системах “вчитель учень”, “батьки - дитина” тощо, а лише створення в школі та поза нею досконалих педагогічних умов, в яких будь-яка навчальновиховна проблема буде переживатися дитиною як життєво важлива і вирішуватися на особистісному рівні як вибір і відповідальність за його наслідки.

Дієвим засобом морального виховання молодших школярів $є$ дитячі періодичні видання, змістово-дидактичний матеріал яких використовується у початковій школі у позакласному читанні [10,96 - 107], у вивченні курсів “Я і Україна" [2, 4, 24 - 27, 28 - 30, 47 - 49] та ін. Визначення шляхів удосконалення морального виховання молодших школярів засобами дитячої періодики і стане предметом подальших досліджень. 


\section{ЛІТЕРАТУРА}

1. Аболіна Т. Цінності моралі. Філософський енииклопедичний словник. Київ, 2002. С. 708709.

2. Байбара Т.М., Бібік Н.М. Я і Україна: підручник для 4 класу. Київ, 2004. 176 с.

3. Виховання. Філософський словник соціальних термінів. Видання третє, доповнене. Харків, 2005. С. 134-136.

4. Дисциплінованість. Словник української мови: В 11 т. Том 2. Київ, 1971. С.287.

5. Киричок В.А. Моральність. Енцииклопедія освіти. Академія пед. наук України; головний ред. В.Г. Кремень. Київ, 2008. С.526-527.

6. Кононко О. Виховання. Енциклопедія освіти. Академія пед. наук України; головний ред. В.Г. Кремень. Київ, 2008. С.87-88.

7. Критерії моральної вихованості молодших школярів. Книга для вчителів / За ред. І. Беха, С. Максименка. Київ, 1989.96 с.

8. Олдингтон Р. Все люди враги. пер. с англ.: О.А. Ефимовская. Москва, 2011. 640 с.

9. Педагогічний пошук / Упоряд. I.М. Баженова; Пер. 3 рос. Київ, 1988. 496 с.

10. Савченко О. Я люблю читати: навчальний посібник $з$ позакласного читання для 4 класу. Київ, 2015. 160 с.

11. Свадковский И.Ф. Нравственное воспитание детей. Москва, 1962. 178 с.

12. Слухняний. Словник української мови: В 11 т. Том 9. Київ, 1978. С.384.

13. Чечулин В.Л. Логико-семантические модели в психологии и их приложение: монография. Пермь: Пермский госсударственный национальный исследовательский университет, 2014. 142 с.

\section{REFERENCES}

1. Abolina, T. (2002). Tsinnosti morali [Values of morality]. Encyclopedic Dictionary of Philosophy. Kyiv, pp.708-709. [in Ukrainian].

2. Baibara, T.M. \& Bibik, N.M. (2004). Ya $i$ Ukraina: pidruchnyk dlia 4 klasu [Me and
Ukraine: a textbook for 4th grade]. Kyiv, 176 p. [in Ukrainian].

3. Vykhovannia (2005). [Education]. Philosophical Dictionary of Social Terms. Third edition, supplemented. Kharkiv, pp. 134-136. [in Ukrainian]. 4.Dystsyplinovanist (1971). [Discipline]. Dictionary of the Ukrainian Language: in 11th v. Vol. 2. Kyiv, p.287. [in Ukrainian].

5. Kyrychok, V.A. (2008). Moralnist [Morality]. Encyclopaedia of education. Academy of pedagogical sciences of Ukraine; (Ed.).V.H. Kremen. Kyiv, pp. 526-527. [in Ukrainian].

6. Kononko, O. (2008). Vykhovannia [Education]. Encyclopedia of Education. Academy of Pedagogical Sciences of Ukraine; (Ed.).V.H. Kremen. Kyiv, pp. 87-88. [in Ukrainian].

7.Kryterii moralnoi vykhovanosti molodshykh shkoliariv. Knyha dlia vchyteliv (1989). [Criteria for moral education of younger students. A book for teachers]. (Ed.). I. Bekh, S. Maksymenko. Kyiv, 96 p. [in Ukrainian].

8. Oldynhton, R. (2011). Vse liudy vrahy [All humans are enemies]. translation from English O.A. Yefimovskaya. Moscov, 640 p. [in Russian].

9. Pedahohichnyi poshuk (1988). [Pedagogical search]. (Ed.). I.M. Bazhenova; Translation from Russian. Kyiv, 496 p. [in Ukrainian].

10. Savchenko, O. (2015). Ya liubliu chytaty: navchalnyi posibnyk z pozaklasnoho chytannia dlia 4 klasu [I love to read: Extra-curricular reading tutorial for 4th grade]. Kyiv, 160 p. [in Ukrainian].

11. Svadkovskyi, Y.F. (1962). Nravstvennoe vospytanye detei [Moral education of children]. Moscov, 178 p. [in Russian].

12. Slukhnianyi, (1978). Slovnyk ukrainskoi movy: V $11 \mathrm{t}$. [Dictionary of the Ukrainian Language: in 11th v.]. Vol. 9. Kyiv, p.384. [in Ukrainian].

13. Chechulyn, V.L. (2014). Lohyko-semantycheskye modely v psykholohyy y ykh prylozhenye: monohrafyia [Logical and semantic models in psychology and their application: monograph]. Perm, 142 p. [in Russian].

Стаття надійшла до редакції 20.09.2019

\section{G5808nc2058080}

"Справедливість полягає у тому, щоб віддати кожному належне".

Тาичерон

давньоримський білособ, літератор

“Моральність - основа всіх людських иінностей".

Альберт Ейнштейн

один з найвизначніших бізиків ХХ століття

\section{G58080.2658080}

